\title{
Application of the environmental impact assessment to medicinal plants cultivation and drying in a hilly area of Campania Region (Southern Italy)
}

\author{
Enrica De Falco, ${ }^{1}$ Maria Pergola, ${ }^{2}$ Annapia Vece, ${ }^{1}$ Costantina Angiuoni, ${ }^{1}$ Giuseppe Celano ${ }^{1}$ \\ ${ }^{1}$ Dipartimento di Farmacia (DIFARMA) Università degli Studi di Salerno, Fisciano (SA); \\ ${ }^{2}$ Ages s.r.l. s - Spin-off Accademico, Università degli Studi della Basilicata, Potenza, Italy
}

\begin{abstract}
Currently, in Italy the cultivation of tobacco has strongly decreased and there is the need to organize substitute production chains that take into account current market demands. Medicinal plants can represent a possible alternative and an opportunity for the Italian agricultural sector. The aim of the present study was to assess the quality and the environmental sustainability of medicinal plants cultivation and processing using different drying techniques in a hilly area of the Campania region. The research was designed to investigate two drying systems (the recovery of a wooden structure for drying tobacco in the open air and a specific electric prototype for drying medicinal plants) and five cultivated medicinal species (marsh-mallow, absinthe, Californian poppy, lemon balm, thyme). To assess and compare quality efficiency and environmental performance, the life cycle assessment methodology was applied according to the ISO 14040-44. The functional unit was the production of one kilo of dried medicinal plants and, to meet the objectives of the research, the system boundaries included the cultivation of the plants, their transport to the drying structure and the herbs drying. Priority was given to primary data in terms of input material typologies and amounts used to estimate direct and indirect emissions. Results showed a good adaptability of the species to the pedo-climatic environment with high biomass yields. Both drying structures allowed to reach a final product
\end{abstract}

Correspondence: Maria Pergola, Ages s.r.l. s - Spin-off Accademico, Università degli Studi della Basilicata, Viale dell'Ateneo Lucano 10, 85100 Potenza, Italy.

Tel.: +39.0971.205269. E-mail: mariateresa_pergola@virgilio.it

Key words: Officinal plants; life cycle assessment; quality assessment; sustainability; eco-compatibility; resilience.

Funding: this research was financially supported by the RIPOT Project - PSR Campania 2007-2013 (measure 124).

Received for publication: 20 June 2019.

Revision received: 23 December 2019.

Accepted for publication: 22 January 2020.

(C) Copyright: the Author(s), 2020

Licensee PAGEPress, Italy

Italian Journal of Agronomy 2020; 15:1505

doi:10.4081/ija.2020.1505

This article is distributed under the terms of the Creative Commons Attribution Noncommercial License (by-nc 4.0) which permits any noncommercial use, distribution, and reproduction in any medium, provided the original author(s) and source are credited. with high quality and low moisture. The cultivation and the drying of one $\mathrm{kg}$ of medicinal plants caused mainly marine and fresh water ecotoxicity, abiotic depletion, eutrophication, air acidification and global warming. The lowest impacts occurred when drying took place in the open air under the wooden structure. The combination of the two systems organized with a first phase of drying in the open air at the individual farms by recovering the tobacco structures, and the next artificial stabilization of the product at a cooperative center, would reduce the overall environmental impact and ensure the quality of the product regardless of the harvesting period. These results could be easily used to support the quality supply chain of medicinal plants with low environmental impacts. Moreover, they highlighted an encouraging approach to evaluate a resilient reorganization when different agricultural productions go into crisis.

\section{Introduction}

Cultivation intensification and specialization often require substantial adaptations when changes occur in the agricultural sector of production including, among other things, the skills of farmers, the possibility of recovering the existing equipment and structures in the farms, the reorganization of the procedures.

Tobacco represented a widely diffused crop throughout Italy where different drying systems were used depending on the typology of tobacco grown and the climatic conditions. In this cultivation, in fact, the drying represented a crucial phase of the process to reach high quality of the product (Müller and Heindl, 2006; Rocha et al., 2011). Currently, the cultivation of tobacco has strongly decreased due to lower profitability and reduction of market demand. Therefore, there is the need to organize substitute production chains that take into account the current market demand.

In this perspective, medicinal plants can represent an interesting alternative to tobacco cultivation due to the large number of species adaptable to very different pedo-climatic conditions and to the growing interest of consumers towards the use of natural and health products, from functional foods to herbal formulations.

Despite the current availability of a large number of synthetic products capable of effectively replacing the medicines, aromas and cosmetics obtainable from plants, there is a renewed interest in natural products from aromatic and medicinal plants. As said by Vitalini et al. (2009), 25\% of all medical prescriptions are based on substances derived from plants or plant-derived synthetic analogues.

Indeed, medicinal plants have long been the subject of a renewed and growing interest, both cultural and economic, due to their properties, which allow their use in traditional and innovative sectors because of the need of new bio-active molecules and the greater attention to models of sustainable development. These species are considered of great importance in human consumption 
and animal foodstuff, and in agrifood industry as natural products to control plants diseases (Torodovic et al., 2016).

Various studies reported the beneficial effects of aromatic plants on antioxidant defense (Paur et al., 2011; Viuda-Martos et al., 2011) and suggested the consumption of aromatic herbs to prevent chronic diseases (Fernandez-Lopez et al., 2012; Santos et al., 2014). Other studies evidenced the potentiality in the food sector as natural preservative for the antioxidant and antibacterial activity (Solorzano-Santos et al., 2012; De Falco et al., 2013, 2014; Senatore et al., 2013; Gallego et al., 2013). The positive effects of essential oils from oregano, rosemary, thyme, sage, basil and others, when used alone or in combination, to extend product shelf life by controlling lipid oxidation and improving the sensory qualities of meat and meat products were reported by Jayasena and Jo (2014).

Worldwide, in the period 2000-2016, there has been an overall growth in both the cultivated area and the production obtained from medicinal plants, as it was reported by FAOstat (2016). At the European level, the statistics referring to 2010 show a small but developing sector, which has recorded an increase in both the number of companies and the areas invested (ISMEA, 2013).

In Italy, medicinal crops are more widespread in the North (47\%), followed by the Center $(29 \%)$ and the South $(24 \%)$. Despite of the increasing demand, the medicinal plants sector does not grow in proportion to the demand of the herbal market, being able to meet the national needs only for $30 \%$. At the same time the demand of Italian products abroad is increasing (ISMEA, 2013). Therefore, the cultivation of medicinal plants could be an opportunity for Italian agricultural sector as long as it is able to assure the quality of products and the low environmental impact of the process (European Commission, 2014).

Finally, the introduction of medicinal plants can take advantage of the solid experience acquired by the farmers in the drying process of tobacco and the availability of specific structures.

The analysis of the environmental impact of the whole life cycle of a product or service is provided by the life cycle assessment (LCA) methodology. The LCA was mainly used to study industrial processes, but in recent years the interest of the application of this methodology in agricultural processes has increased significantly (Fedele, 2010; Ronga et al., 2019). This methodology was created to study all the environmental impacts related to an entire production process (Consoli et al., 1993). Therefore, referring to the agrifood sector, the LCA determines the impacts deriving from the cultivation and processing of crops and connected to the realization of the production factors. A wide review of LCA applications in the fruit sector can be found in Cerutti et al. (2014). Nevertheless, to our knowledge, there are not references in literature on the environmental impacts associated with medicinal plants cultivation and drying, despite the increasing interest of the sector. Eltawil et al. (2018) performed an environmental analysis $\left(\mathrm{CO}_{2}\right.$ emissions and mitigation) of hybrid solar tunnel dryer with PV system and solar collector for drying mint (Mentha viridis) starting from the energy analysis. Since electricity generation from coal is about $0.98 \mathrm{~kg}$ of $\mathrm{CO}_{2}$ eq $\mathrm{kWh}^{-1}$ as average $\mathrm{CO}_{2}$ equivalent intensity at the source, they multiplied 0.98 for the embodied energy, that is the total energy required to produce any items, things or services (Eltawil et al., 2018), but they did not perform a complete LCA study.

According to this, the aim of the present study was the assessment of the quality and the environmental sustainability of medicinal plants cultivation and processing, using different drying techniques, testing their quality efficiency, as well as their environmental performance, in a hilly area of the Campania region (Southern
Italy), partly recovering the pre-existing farm structures used for tobacco. To assess and compare these aspects, the LCA methodology was applied. In particular, the research was designed to investigate two drying systems (a wooden structure for tobacco drying in open air and a specific electric prototype for drying medicinal plants) and five cultivated medicinal species. All this to understand if the results could be useful for the sustainable reorganization of the production system too.

\section{Materials and methods}

\section{Description of the study area and the analyzed systems}

The study was performed in the province of Benevento (Campania, Southern Italy) where the cultivation of tobacco constituted one of the most important productive sector. In this territory the chain of medicinal plants may represent an alternative because of the variability of the pedo-climatic conditions that makes it possible to cultivate a large number of medicinal species, the widespread diffusion of integrated farming system, the presence of established producers' organizations for the first processing and marketing of the product (Regione Campania, 2013). In addition the research took into account the possibility of reconverting easily tobacco farms equipment with appropriate adaptations.

The experiment was carried out in a private farm at San Giorgio del Sannio (4104'43.83’N, 1454’00.71'E, $267 \mathrm{~m}$ a.s.1.) during the period May 2013 - October 2014 on five plants species: marsh-mallow (Althaea officinalis L.), absinthe (Artemisia absinthium L.), Californian poppy (Escholtzia californica Chamisson), lemon balm (Melissa officinalis L.), and thyme (Thymus vulgaris L.). The area is characterized by Mediterranean climate. Annual rainfall is $770 \mathrm{~mm}$ concentrated mostly in the autumn and winter season $(492 \mathrm{~mm})$ and annual mean temperature is $15^{\circ} \mathrm{C}$, as an average of the years $2008-2018$.

The five crops were transplanted in 2013 on a flat silty loam soil (Haplicluviosols and Eutricvertisols) (FAO, IUSS, ISRIC, 2006). The analysis of the soil and the irrigation water were made before the beginning of the medicinal plants cultivation to evaluate the quality of the environment by prof. M. Catauro of the Vanvitelli University. The results showed no pollutants, according to the specific Italian law (D.L. 152/06, Italian G.U. 88 14/2006). During the period of the trial the yield of biomass for each crop was determined (Decree of Ministry of the Environment, 2006).

Two drying systems were compared: an air-based system by a wooden structure traditionally used for tobacco and artificial drying through a specific electric prototype for medicinal plants.

Usually, every farm has its wooden structure (one or more) for tobacco air drying located near the farm centre, not far away from the cultivated fields. They are covered structures constructed in such a way as to let the natural passage of air but protect the product from the direct sun and rain.

The structure used for the experimentation was located at the farm where the cultivation was carried out. It was able to treat around 128.6 ton of fresh biomass per year. As shown in Figure 1, the building was open and had $288 \mathrm{~m}^{2}$ usable area within. In structural terms, the building was made of cast-in-situ concrete as regards the pillars, the foundations and the pavement, whilst a load bearing structure made of wood bars was used for the building covering. Below this structure, 48 polyethylene drying racks were set up, $18 \mathrm{~m}$ long and $1.7 \mathrm{~m}$ wide. During the period of drying experimentation temperature and relative humidity of the air outside and inside the 
structure were recorded by a meteorological station (PCE-FWS 20 set with 5 min logging interval). For each species (marsh-mallow, absinthe, Californian poppy, lemon balm, thyme) representative samples were placed on grilled cassettes with a material thickness of about $7 \mathrm{~cm}$ and stacked so as to allow a sufficient quantity of air to pass, with three repetitions, in two different periods (May and October). The samples were weighed every day until the weight remained unchanged. The drying process was considered complete when the weight of the samples remained constant.

The second drying system (electric dryer) was also located at San Giorgio del Sannio (4106'47.71'N, 1453'49.19'E), inside a producers' organizations structure, as a custom used for the first processing and marketing of tobacco and far away $15 \mathrm{~km}$ from the crop production site. It was a static drier modular prototype (Figure 2 ). The operating principle was based on the removal of moisture from the products through the forced circulation of hot air. The products were manually loaded onto food PP (polypropylene) perforated trays installed on AISI 304 stainless steel moving carts. The machine operated non-continuously. The aerothermal group consisted of water or steam heat exchange batteries, helical electrical fans and suction air intake filters. It was used to supply circulating hot air around the product to be dried. For LCa evaluation has been taken into consideration a drying module able to treat around 75 ton of fresh biomass per year. It consisted of 3 AISI 304 stainless steel carts and 60 food PP (polypropylene) grid stackable trays $(0.6 \times 0.6 \times 0.05 \mathrm{~m})$ for each cart. The drying time was fixed in $12 \mathrm{~h}$ for the thymus and $18 \mathrm{~h}$ for the other species, on the basis of previous set-up. The main features of the experimental systems are reported in Tables 1 and 2. The five systems, which fell within the same farm, were managed in a similar way, while differences were took into account for each species according to the transport and drying system.

\section{Quality assessment}

At the end of every drying cycle, for each species and both drying systems the biomass residual moisture content was determined on a representative sample with three repetitions. All statistical analyses were performed by MSTAT-C software package (Michigan State University, MI, USA). Preventive analysis for the normality of the variance and ANOVA (referring to harvesting moisture and residual moisture after drying) for the different species and the two harvesting time were carried out. Means were separated according to Tukey's test $(\mathrm{P}=0.01)$. The quality control was carried out by filling a sheet reporting the main parameters defined after an appropriate bibliographic consultation; they were the following: leaf/steam ratio, leaf lamina colour, aroma, presence of extraneous materials, mould, damage from insects or fungi (WHO, 2011; European Pharmacopoeia, 2005).

\section{Environmental analysis}

An in-depth analysis was performed for each of the two aforementioned drying systems using the LCA method, according to the ISO 14040-44:2006 (ISO, 2006a, 2006b). The analysis was articulated in the following interrelated phases: Functional Unit and system boundary; inventory data collection and emissions; LCA and interpretation.

\section{Functional unit and system boundary}

For the development of the whole assessment, both the functional unit (FU) and the system boundaries were defined. The FU in the LCA provides a reference to which the inputs and outputs of the inventory are related and allows the comparison between systems or alternatives (International Organisation for Standardisation, 2006a, 2006b). The function of the systems under study was to produce dried medicinal herbs. Therefore, the basis for the comparison of the different drying alternatives, named the FU of the service delivered, was defined as the production of one kilo of dried medicinal plants. Consequently, to meet the objectives of the present research, the system boundaries included the cultivation of the medicinal plants, their transport to the drying structure and the herbs drying. The transportation of the produced dried officinal plants to their final destina-

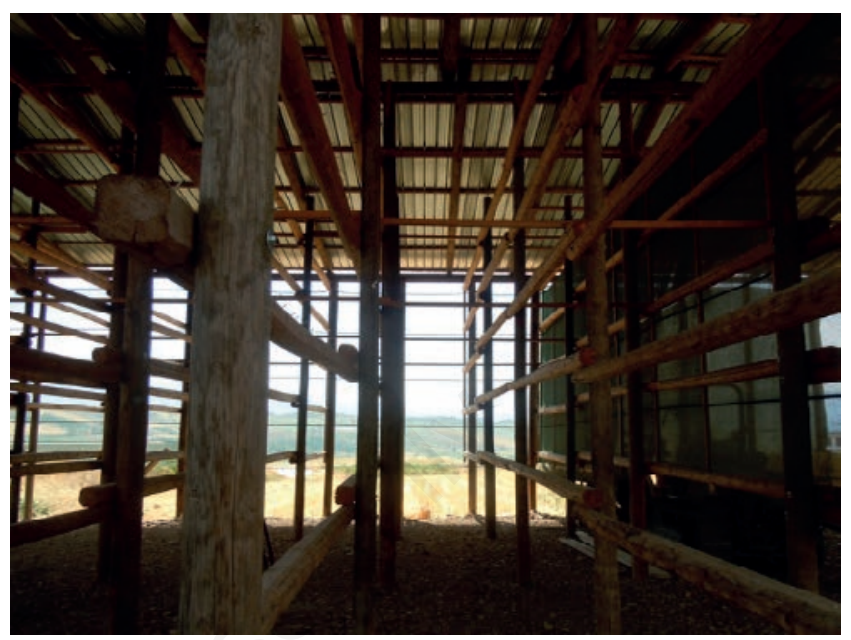

Figure 1. The wooden structure considered in the study.
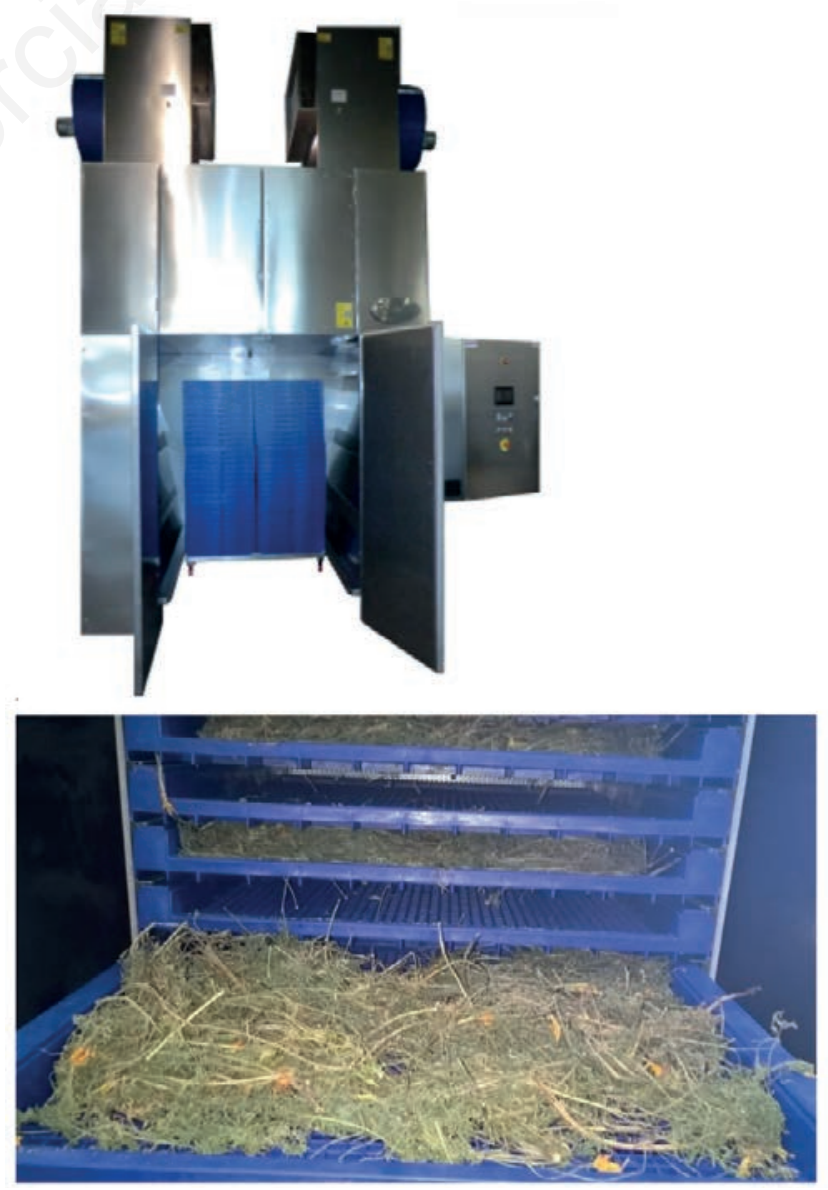

Figure 2. The electric dryer considered in the study. 
tion was excluded because it was outside the scope of this research.

As it was reported by Pergola et al. (2016), agricultural systems generate impacts and avoided impacts in a number of unit steps. So, the system boundaries was designed in order to enable the accounting of the main impacts coming from the following unit phases: i) the cultivation of medicinal plants; ii) the transportation of those materials to the drying structures; iii) the construction of the capital equipment and infrastructures; iv) the officinal herbs drying processing.

Referring to the cultivation, the following farming operations were taken into account: soil preparation, pre-transplantation fertilization, seedlings transport, transplantation, soil tillage (mechanical weeding), fertilization, irrigation and harvesting. To be consistent with the aim of this study, attention was focalized upon the construction of the capital equipment or infrastructures in all processes; the fuel usage in the various agricultural operations; the electricity consumption associated with the drying phase and facility; the fertilizers used. For a better understanding, the system boundaries with indication of the input and output flows were depicted in Figure 3.

\section{Inventory data collection and emissions}

Data associated to the studied systems (quantities of machinery, fuel, lubricants and other items) were collected in situ using a data collection sheet. This information was gathered from farmers. Inputs used in the examined systems were reported in Table 3.

Priority was given to using primary data in terms of input material typologies and amounts used. Additionally, as a standard practice in the LCAs, for each operation taken into account (soil preparation, fertilization, seedlings transport, transplantation, soil tillage, irrigation, harvesting, transport and drying process), the active ingredient of each product, the quantity of machines utilized and the amount of fuel and lubricants consumed were calculated and used in the analysis to estimate direct and indirect emissions.

\section{Direct field emissions}

Direct emissions from fuel and lubricants were taken from SimaPro's LCI databases. Referring to fertilizers, an entire mineral balance was not undertaken to estimate emissions from them.

In the present study nitrogen emissions from the cultivation were determined in accordance with Brentrup et al. (2000), Bouwman (1995) and IPCC (2006). Exact rates of N emission rates can greatly vary depending on soil type, climatic conditions and agricultural management practices.

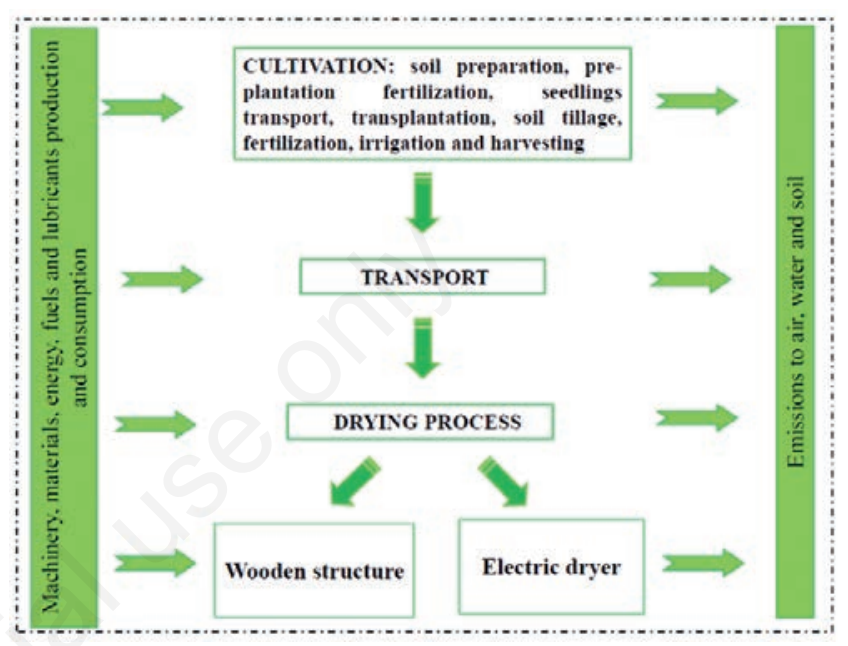

Figure 3. The system boundaries and input and output flows for the analyzed systems.

Table 1. The main features of the examined medicinal plants cultivation.

\begin{tabular}{|c|c|c|c|c|}
\hline $\begin{array}{l}\text { Systems } \\
\text { characteristics }\end{array}$ & Absinthe & Californian poppy & Lemon balm & Thyme \\
\hline Althaea officinalis L. & Artemisia absinthium L. & Escholtzia californica Chamisson & Melissa officinalis $\mathrm{L}$. & Thymus vulgaris $\mathrm{L}$. \\
\hline Planting density & & $\begin{array}{c}\text { 33,330 plants ha }{ }^{-1} \\
(1 \mathrm{~m} \times 0.30 \mathrm{~m})\end{array}$ & & \\
\hline Plants age (years) & & 1 & & \\
\hline Soil characteristics & & Silty loam & & \\
\hline Cultivation system & & Integrated & & \\
\hline Irrigation & & Drip irrigation system & & \\
\hline Soil management (weed control) & & Manual scarbing - mechanical weeding & & \\
\hline Fertilization & & Mineral/annual & & \\
\hline Harvesting method & & Mechanical & & \\
\hline $\begin{array}{l}\text { Average yield } \\
\text { (ton ha }{ }^{-1} \text { year }^{-1} \text { dry matter) }\end{array}$ & 4.8 & 3.4 & 3.8 & 4.1 \\
\hline
\end{tabular}

Table 2. The differences in transport modes, construction features and distance from the field to the drying structure for the two examined drying systems.

$\begin{array}{ccc}\text { Items } & \text { Wooden structure } & \text { Electric dryer } \\ \text { Transport } & \text { Tractor New Holland T4030 - } 57 \mathrm{hp} & \text { Fiat Doblò minivan } \\ \text { Construction features } & \text { Cement and chestnut poles; } & \text { AISI 304 stainless steel; electrical materials; } \\ & \text { Polyethylene high density } & \text { polypropylene }\end{array}$


In the present study, $\mathrm{N}$ leaching was considered insignificant because the cultivation systems under study foresees the continuous presence of plants and the difference between precipitation in the rainy season and the potential evaporation in the same period is close to the water holding capacity of the soil (well structured silty loam soil). In addition, crops were planted on flat land (this also reduced $\mathrm{N}$ losses by run-off) and irrigated by means of a drip irrigation system which avoided $\mathrm{N}$ losses during the summer period. Phosphate emissions could be calculated following Nemecek and Kägi (2007), who underlined that a part of the phosphorus (P) is lost due to leaching, run-off and soil erosion through water, causing eutrophication. In this study $\mathrm{P}$ losses were not considered for the reasons previously taken into account for $\mathrm{N}$ losses.

\section{Embodied emissions}

Secondary data were extrapolated from international databases of scientific importance and reliability, like the Ecoinvent 3 (vers. 3, 2013; http:/www.ecoinvent.org/database/database.html). In particular, this was done for the production of diesel, electricity, lubri- cants and fertilizers used in the systems investigated, including the accounting of the resulting emissions; for the construction of agricultural vehicles and capital equipment (wooden structure and electric dryer).

Referring to electricity, the dataset describes the transformation from medium to low voltage, as well as the distribution of electricity at low voltage. In particular, it encompasses the electricity production in Italy and from imports, the transmission network as well as the direct SF6-emissions to air. Also, electricity losses during low-voltage transmission and transformation from medium voltage were accounted for (Ecoinvent, 2013). The fuel consumption model included the transportation of the product from the refinery to the end user. With regard to the amount of agricultural vehicles, equipment and other structures, the necessary amounts for each field operation and values such as life span, annual working time and working time for each operation, have been collected at farms and used to modify the Ecoinvent unit process. In particular, their inventory took only into account the use of resources and

Table 3. Inputs used in the examined medicinal plants cultivation. Values are referred to one kilo of dried medicinal plants produced.

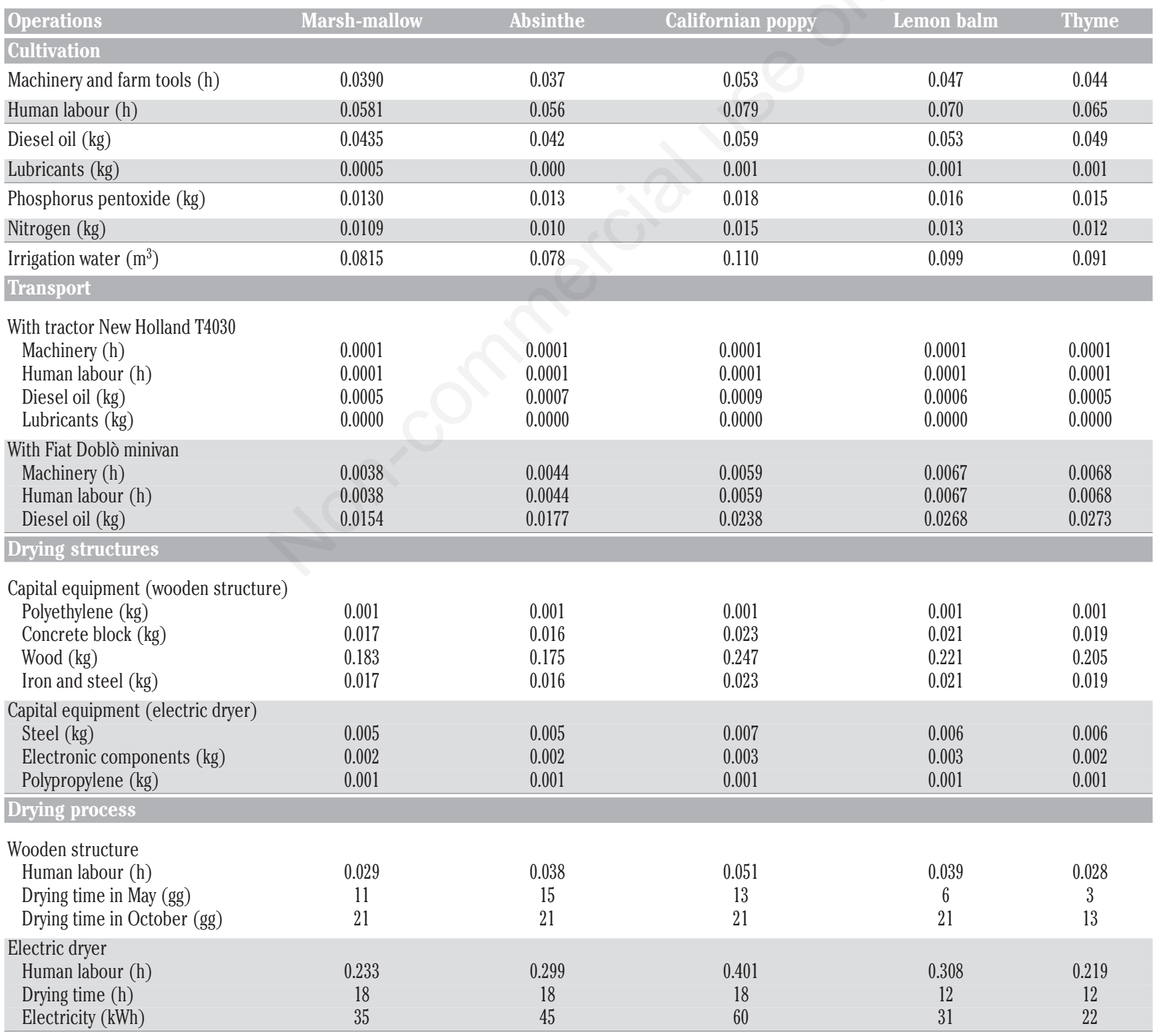


the amount of emissions during their production, maintenance, repair and final disposal. The Ecoinvent module for the fertilizers utilized (phosphorus pentoxide and nitrogen) took into account their production from ammonia, phosphate and carbon dioxide. Transports of the intermediate products were included, as well as the transport of the fertilizer products from the factory to the regional storehouse.

\section{Life cycle assessment}

The impact assessment was performed using SimaPro 8.02, with the problem oriented LCA method developed by the Institute of Environmental Sciences of the University of Leiden (CML et al., 2001). The following impact potentials were evaluated according to the selected method: abiotic depletion (AD); abiotic depletion (fossil fuels) $\left(\mathrm{AD}_{\mathrm{FF}}\right)$; global warming potential $(\mathrm{GWP})$ or climate change; photochemical oxidation (PO); ozone layer depletion (ODP); human toxicity (HT); fresh water aquatic ecotoxicity (FWE); marine aquatic ecotoxicity (MAE); terrestrial ecotoxicity (TE); air acidification (AA) and eutrophication (EU). Moreover, the impact assessment was performed following a mid-point approach and, so, using equivalent indicators (specific for the impact categories considered) to express the LCA results in the form of characterisation values. In order to assess the contribution of each impact category on the overall environmental problem, Normalization of the characterization results was done using as Normal value the region Europe 25 (PRé, various authors, 2015).

\section{Results and discussion}

\section{Yield and qualitative assessment}

Data reported in Table 4 showed that for all species it was possible to perform more than one harvesting; moreover, total yields were high and comparable to those reported in the literature for Italian pedo-climatic environments (Catizone et al., 2013).

Data related to drying processes are reported in Table 5. Harvesting humidity was between $70.8 \%$ (Thyme in October) and $91.8 \%$ (Californian poppy in May) in relation to the different species and the harvesting time.

The drying under wooden structure allowed to reach very satisfactory results when the plants were harvested in May because all the species reached residual moisture values next to $10 \%$, the condition to ensure a good conservation. The highest moisture values were registered for absinthe (14.3\%) and Californian poppy (12.9\%). Great interest results were those relating to lemon balm and thyme for which the drying period was limited to 6 and 3 days, respectively.

Both the drying parameters (residual moisture and drying duration) were higher in occasion of October harvesting. These results found a justification in the less favourable climate conditions occurred in this period as it was evidenced by temperature and relative humidity data recorded outdoor and indoor (Table 6).

Regarding the electric dryer, the best results were registered for thyme with a drying duration of $12 \mathrm{~h}$ and a residual moisture of about $8 \%$. The drying duration of $18 \mathrm{~h}$ was found to be satisfactory - in both harvesting months (May and October) - for marsh-mallow and lemon balm that reached a residual moisture of about $10 \%$. Also in this case, the drying process resulted more difficult for absinthe and Californian poppy as they would need a longer drying time (Table 5).

The quality control of the products after the drying process highlighted that all the samples were within the standards for the parameters that were measured, without the presence of moulds, insects or fungi, regardless of the drying structure and period.

These results allow us to hypothesize the suitability of combined use of the two drying systems to optimize the process, especially when the external conditions are not favourable. In fact, it is possible to use the drying in open air in the first phase of the treatment and then the artificial one to complete the process up to the humidity for the optimal conservation of the product.

Table 4. Results of total yield during the period of the trial for each medicinal plants species considered.

\begin{tabular}{lccc} 
Species & $\begin{array}{c}\text { Number of } \\
\text { harvesting }\end{array}$ & $\begin{array}{c}\text { Fresh biomass } \\
(\mathrm{kg})\end{array}$ & $\begin{array}{c}\text { Dry biomass } \\
(\mathrm{kg})\end{array}$ \\
Marsh-mallow & 2 & 21,400 & 4,600 \\
Absinthe & 2 & 34,400 & 4,800 \\
\hline Californian poppy & 2 & 31,300 & 3,400 \\
Lemon balm & 2 & 22,500 & 3,800 \\
\hline Thyme & 2 & 19,000 & 4,100 \\
\hline
\end{tabular}

Table 5. Drying quality parameters for each medicinal plants species considered and distinct for the two analyzed drying systems.

\begin{tabular}{|c|c|c|c|c|c|c|}
\hline \multirow[t]{3}{*}{ Species } & \multirow{2}{*}{\multicolumn{2}{|c|}{ Harvesting moisture (\%) }} & \multicolumn{4}{|c|}{ Residual moisture after drying (\%) } \\
\hline & & & \multicolumn{2}{|c|}{ Drying under wooden structure } & \multicolumn{2}{|c|}{ Drying with electric dryer } \\
\hline & May & October & May & October & May & October \\
\hline Marsh-mallow & $77.6^{\mathrm{bc}}$ & $77.9^{\mathrm{bc}}$ & $10.0^{c}$ & $16.1^{\mathrm{bc}}$ & $10.0^{b c d}$ & $10.0^{\mathrm{bcd}}$ \\
\hline Duration of treatment* & - & - & (11) & $(21)$ & $(18)$ & $(18)$ \\
\hline Absinthe & $84.6^{\mathrm{ab}}$ & $88.1^{\mathrm{a}}$ & $14.3^{\mathrm{bc}}$ & $26.9^{\mathrm{a}}$ & $16.4^{\mathrm{ab}}$ & $17.4^{\mathrm{a}}$ \\
\hline Duration of treatment* & - & - & (15) & (21) & (18) & (18) \\
\hline Californian poppy & $91.1^{\mathrm{a}}$ & $88.6^{\mathrm{a}}$ & $12.9^{\mathrm{bc}}$ & $20.0^{\mathrm{ab}}$ & $14.0^{\mathrm{abc}}$ & $12.5^{\mathrm{abcd}}$ \\
\hline Duration of treatment* & - & - & (11) & (21) & (18) & (18) \\
\hline Lemon balm & $85.0^{\mathrm{ab}}$ & $85.1^{\mathrm{ab}}$ & $10.8^{c}$ & $15.1^{\mathrm{bc}}$ & $9.7^{\mathrm{cd}}$ & $9.7^{\mathrm{cd}}$ \\
\hline Duration of treatment* & - & - & $(6)$ & (21) & (18) & (18) \\
\hline Thyme & $79.5^{\mathrm{b}}$ & $70.8^{c}$ & $10.5^{c}$ & $14.0^{\mathrm{bc}}$ & $8.8^{\mathrm{cd}}$ & $8.0^{\mathrm{d}}$ \\
\hline Duration of treatment* & - & - & (3) & (13) & (12) & (12) \\
\hline
\end{tabular}

a-dMeans followed by different letters in the same column for every parameter are significantly different $\left(\mathrm{P}=0.01\right.$; Tukey's test). ${ }^{*}$ The duration of treatment was expressed in days for the drying under wooden structure and in hours for the electric dryer. 
This type of management can be easily adopted within producer organizations by providing a first phase at the individual farms, through the recovery of the drying equipment in open air, and a subsequent phase of biomass stabilization at a cooperative centre, until the optimal moisture content is reached, through the adoption of an artificial system.

\section{Environmental impacts results and interpretation}

Life cycle impacts per $\mathrm{kg}$ of dried product are shown in Table 7. The system with electric dryer led to higher environmental impacts by referring to all impact categories and this was even more evident by observing the normalized data (Figure 4). Besides, they underlined as, in both systems, the marine aquatic ecotoxicity was the category mostly affected by the impact, followed by fresh water aquatic ecotoxicity, abiotic depletion (fossil fuels), eutrophication, air acidification and global warming. Depending on the species, the production of $1 \mathrm{~kg}$ of medicinal plants with drying by electric dryer: i) consumed from 259 to 438 $\mathrm{MJ}$ of natural resources (including energy resources), such as iron ore and crude oil; ii) emitted from 18 to $31 \mathrm{~kg}$ of $\mathrm{CO}_{2} \mathrm{eq}$, responsible of GWP; iii) issued from $19412.61 \mathrm{~kg}$ to $27406.04 \mathrm{~kg}$ of 1.4 dichlorobenzene equivalent; iv) produced from 0.004 to $0.006 \mathrm{~kg}$ of $\mathrm{C}_{2} \mathrm{H}_{4}$ responsible of photochemical oxidation; v) emitted from 0.08 to $0.13 \mathrm{~kg}$ of $\mathrm{SO}_{2}$ eq causing air acidification; vi) produced from 0.02 to $0.04 \mathrm{~kg} \mathrm{PO}^{3-}$ eq, responsible of eutrophication.

Referring to the species, Californian poppy had the greatest impact in both systems (Table 7), mainly due to its lower productivity. On average, the cultivation was the operation that had the greatest impact in the system with drying under wooden structure,

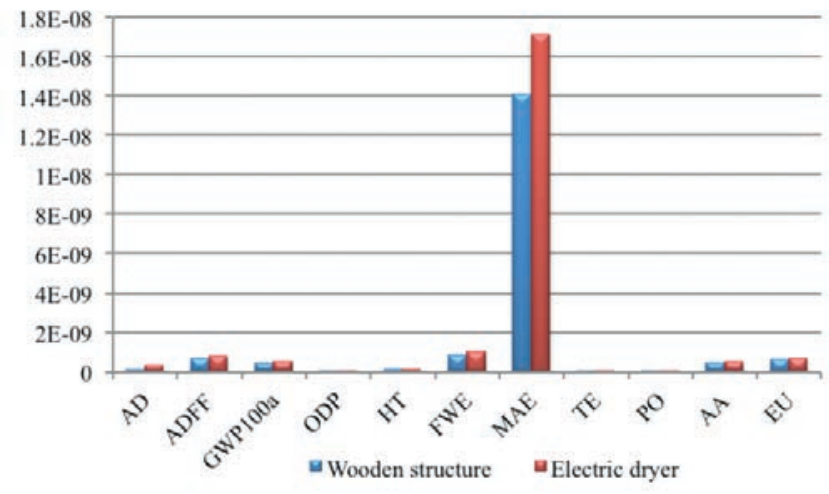

Figure 4. Normalization of the impact categories for the two analyzed drying systems. $\mathrm{AD}$, abiotic depletion; $\mathrm{AD}_{\mathrm{FF}}$, abiotic depletion fossil fuels; GWP $_{100 a}$, global warming potential or climate change; ODP, ozone layer depletion; HT, human toxicity; FWE, fresh water aquatic ecotoxicity; MAE, marine aquatic ecotoxicity; TE, terrestrial ecotoxicity; PO, photochemical oxidation; AA, air acidification; EU, eutrophication.

Table 6. Average temperature and humidity data registered outdoor and indoor in the months of May and October.

\begin{tabular}{lcccc} 
Month & \multicolumn{2}{c}{ Indoor } & \multicolumn{2}{c}{ Outdoor } \\
& $\begin{array}{c}\text { Temperature } \\
\left({ }^{\circ} \mathrm{C}\right)\end{array}$ & $\begin{array}{c}\text { Humidity } \\
(\%)\end{array}$ & $\begin{array}{r}\text { Temperature } \\
\left({ }^{\circ} \mathrm{C}\right)\end{array}$ & $\begin{array}{c}\text { Humidity } \\
(\%)\end{array}$ \\
May & 18.3 & 68.6 & 19.7 & 68.4 \\
October & 16.5 & 74.6 & 17.4 & 73.0 \\
\hline
\end{tabular}

Table 7. Life cycle impacts per $\mathrm{kg}$ of dried product for each medicinal plants species considered and distinct for the two analyzed drying systems.

\begin{tabular}{|c|c|c|c|c|c|c|}
\hline Impact categories & Unit kg ${ }^{-1}$ & $\begin{array}{l}\text { Marsh-mallow } \\
\text { Drying under wo }\end{array}$ & $\begin{array}{l}\text { Absinthe } \\
\text { den struct }\end{array}$ & Californian poppy & Lemon balm & Thyme \\
\hline $\mathrm{AD}$ & $\mathrm{kg}$ Sb eq & 0.0000011 & 0.0000012 & 0.0000016 & 0.0000014 & 0.0000011 \\
\hline $\mathrm{AD}_{\mathrm{FF}}$ & MJ & 2.54 & 2.65 & 3.65 & 3.16 & 2.47 \\
\hline $\mathrm{GWP}_{100 \mathrm{a}}$ & $\mathrm{kg} \mathrm{CO} 2 \mathrm{eq}$ & 0.27 & 0.27 & 0.38 & 0.33 & 0.27 \\
\hline ODP & kg CFC-11 eq & 0.00000001 & 0.00000001 & 0.00000001 & 0.00000001 & 0.00000001 \\
\hline HT & kg 1,4-DB eq & 0.14 & 0.15 & 0.20 & 0.17 & 0.12 \\
\hline FWE & kg 1,4-DB eq & 0.06 & 0.06 & 0.08 & 0.07 & 0.05 \\
\hline MAE & $\mathrm{kg} 1,4-\mathrm{DB}$ eq & 198.19 & 205.95 & 284.36 & 246.79 & 190.42 \\
\hline $\mathrm{TE}$ & kg 1,4-DB eq & 0.0004 & 0.0005 & 0.0007 & 0.0006 & 0.0003 \\
\hline PO & $\mathrm{kg} \mathrm{C}_{2} \mathrm{H}_{4} \mathrm{eq}$ & 0.0001 & 0.0001 & 0.0001 & 0.0001 & 0.0001 \\
\hline $\mathrm{AA}$ & $\mathrm{kg} \mathrm{SO}_{2} \mathrm{eq}$ & 0.002 & 0.002 & 0.002 & 0.002 & 0.002 \\
\hline $\mathrm{EU}$ & $\mathrm{kg} \mathrm{PO}_{4}---\mathrm{eq}$ & 0.001 & 0.001 & 0.001 & 0.001 & 0.001 \\
\hline \multicolumn{7}{|c|}{ Drying in electric dryer } \\
\hline $\mathrm{AD}$ & $\mathrm{kg} \mathrm{Sb}$ eq & 0.0009 & 0.0006 & 0.0008 & 0.0009 & 0.0012 \\
\hline $\mathrm{AD}_{\mathrm{FF}}$ & MJ & 330.83 & 310.65 & 438.56 & 271.87 & 259.50 \\
\hline $\mathrm{GWP}_{100 \mathrm{a}}$ & $\mathrm{kg} \mathrm{CO} 2 \mathrm{eq}$ & 23.13 & 21.70 & 30.63 & 19.06 & 18.22 \\
\hline ODP & kg CFC-11 eq & 0.000003 & 0.000003 & 0.000004 & 0.000002 & 0.000002 \\
\hline HT & kg 1,4-DB eq & 10.00 & 7.57 & 10.69 & 9.38 & 11.05 \\
\hline FWE & kg 1,4-DB eq & 7.47 & 5.68 & 8.01 & 6.98 & 8.20 \\
\hline MAE & kg 1,4-DB eq & 24667.81 & 19399.30 & 27387.24 & 22650.13 & 25957.83 \\
\hline $\mathrm{TE}$ & kg 1,4-DB eq & 0.065 & 0.061 & 0.086 & 0.053 & 0.051 \\
\hline $\mathrm{PO}$ & $\mathrm{kg} \mathrm{C}_{2} \mathrm{H}_{4} \mathrm{eq}$ & 0.005 & 0.004 & 0.006 & 0.004 & 0.004 \\
\hline $\mathrm{AA}$ & $\mathrm{kg} \mathrm{SO}_{2} \mathrm{eq}$ & 0.102 & 0.094 & 0.132 & 0.085 & 0.084 \\
\hline EU & $\mathrm{kg} \mathrm{PO}_{4}--\mathrm{eq}$ & 0.036 & 0.029 & 0.041 & 0.033 & 0.038 \\
\hline
\end{tabular}

$\mathrm{AD}$, abiotic depletion; $\mathrm{AD}_{\mathrm{FF}}$, abiotic depletion fossil fuels; $\mathrm{GWP}_{100 \mathrm{a}}$, global warming potential or climate change; ODP, ozone layer depletion; HT, human toxicity; FWE, fresh water aquatic ecotoxicity; MAE, marine aquatic ecotoxicity; TE, terrestrial ecotoxicity; $\mathrm{PO}$, photochemical oxidation; $\mathrm{AA}$, air acidification; EU, eutrophication. 
causing mainly eutrophication, air acidification, global warming and abiotic depletion (Figure 5). In the artificial drying system, the drying process was the most impactful operation, representing more than $90 \%$, if not $100 \%$, of the total impact, mainly for the energy consumed, causing above all ozone layer depletion, global warming, terrestrial ecotoxicity, abiotic depletion, photochemical oxidation and air acidification. The transport impact was low in both systems. These results strongly support the combination of the two drying systems that could allow energy saving and environmental impact reduction. The analysis of the contribute of the different cultivation operations to the environmental impact is reported in Table 8. Data showed that it was due mainly to fertilization (and particularly to direct emissions from the soil) whose impact affected from $43 \%$ to $88 \%$ depending on the impact category.

\section{Conclusions}

The findings coming from this research fill the gaps of knowledge in the available literature about the environmental sustainability of cultivation and drying process of medicinal plants, a growing worldwide sector.

The results on the analysis of quality efficiency and environmental performance of the two analyzed drying structures showed a strong difference between the set of environmental impacts from the electric drying system and that in open air, being lesser the former system. The results of drying in open air led to good quality products with optimal humidity for conservation during the spring period when the weather conditions were more favourable, although some species even in this period did not reach the optimal humidity. On the contrary, in the autumn period only for some species it was possible to reach a humidity close to the optimal one with very long drying times. Among the species, thyme, lemon balm and marsh-mallow have shown excellent adaptation to air drying while absinthe and Californian poppy only a little. So it is possible to combine the drying systems in the less favourable periods or with the most difficult species, as absinthe or Californian poppy. These results can also be applied to evaluate different organizational forms based on reducing the environmental impact. The adoption of double drying (in open air and artificial), in fact, allows not to oversize the artificial drying system and achieve a high quality product for all species and in all periods of the year.
In this model, the herbals pre-treated by the individual farms can be stabilized in a centralized structure, with a reduced environmental impact compared to the artificial drying alone. This hypothesis can be easily transferred in a resilient model for the supply chain of quality products of medicinal plants.

Finally, the Authors believe that the reliability of the results make them readily accessible and useful for farmers, farmer associations, technicians and local politicians to develop a quality supply chain, but also to preserve and transfer to future generations a wealth of centuries-old knowledge, techniques and artifacts.
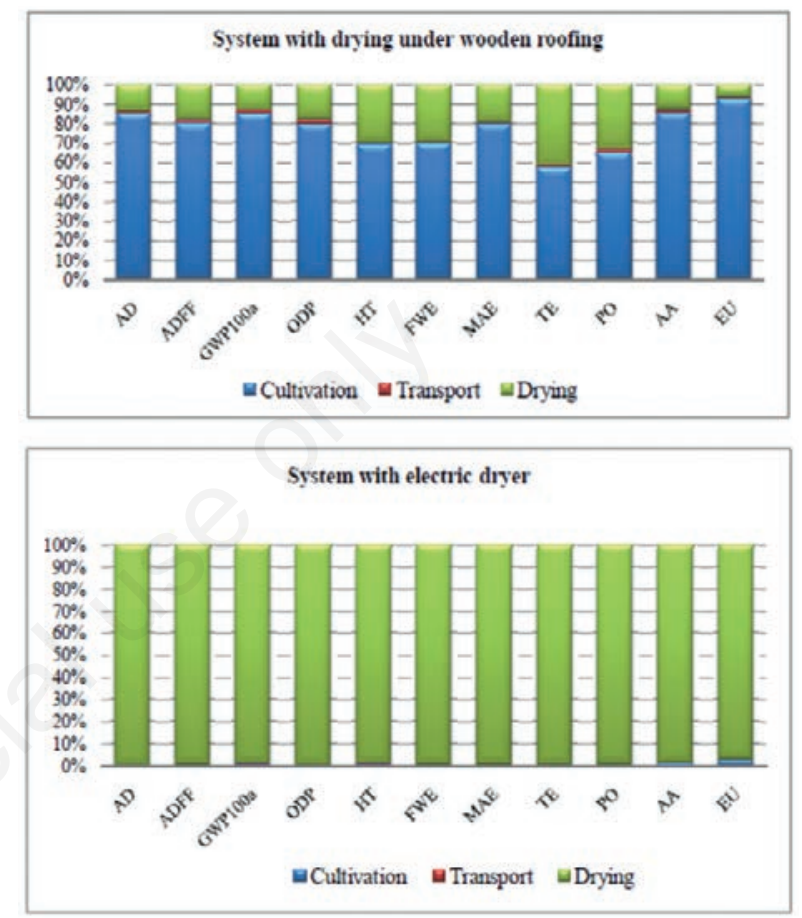

Figure 5. The contribution of each operation to the impact categories per $\mathrm{kg}$ of dried product obtained from the two analyzed drying systems. $\mathrm{AD}$, abiotic depletion; $\mathrm{AD}_{\mathrm{FF}}$, abiotic depletion fossil fuels; $\mathrm{GWP}_{100}$, global warming potential or climate change; ODP, ozone layer depletion; HT, human toxicity; FWE, fresh water aquatic ecotoxicity; MAE, marine aquatic ecotoxicity; TE, terrestrial ecotoxicity; PO, photochemical oxidation; AA, air acidification; EU, eutrophication.

Table 8. The contribution of the cultivation operations on the different impact categories (values are in percentage).

\begin{tabular}{|c|c|c|c|c|c|c|c|}
\hline 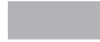 & Harrowing & Fertilization & Transplant & Seedlings transport & Mechanical weeding & Irrigation & Harvesting \\
\hline $\mathrm{AD}$ & $1 \%$ & $88 \%$ & $2 \%$ & $0 \%$ & $2 \%$ & $7 \%$ & $0 \%$ \\
\hline $\mathrm{AD}_{\mathrm{FF}}$ & $6 \%$ & $43 \%$ & $11 \%$ & $0 \%$ & $22 \%$ & $18 \%$ & $1 \%$ \\
\hline $\mathrm{GWP}_{100 \mathrm{a}}$ & $4 \%$ & $64 \%$ & $7 \%$ & $0 \%$ & $14 \%$ & $10 \%$ & $1 \%$ \\
\hline ODP & $8 \%$ & $44 \%$ & $13 \%$ & $0 \%$ & $28 \%$ & $5 \%$ & $1 \%$ \\
\hline HT & $2 \%$ & $74 \%$ & $3 \%$ & $0 \%$ & $4 \%$ & $17 \%$ & $0 \%$ \\
\hline FWE & $1 \%$ & $73 \%$ & $2 \%$ & $0 \%$ & $3 \%$ & $20 \%$ & $0 \%$ \\
\hline MAE & $1 \%$ & $74 \%$ & $2 \%$ & $0 \%$ & $2 \%$ & $21 \%$ & $0 \%$ \\
\hline $\mathrm{TE}$ & $2 \%$ & $65 \%$ & $3 \%$ & $0 \%$ & $5 \%$ & $24 \%$ & $0 \%$ \\
\hline PO & $6 \%$ & $44 \%$ & $10 \%$ & $0 \%$ & $17 \%$ & $21 \%$ & $1 \%$ \\
\hline $\mathrm{AA}$ & $5 \%$ & $58 \%$ & $8 \%$ & $0 \%$ & $17 \%$ & $11 \%$ & $1 \%$ \\
\hline$\underline{\mathrm{EU}}$ & $2 \%$ & $71 \%$ & $3 \%$ & $0 \%$ & $6 \%$ & $19 \%$ & $0 \%$ \\
\hline
\end{tabular}

$\mathrm{AD}$, abiotic depletion; $\mathrm{AD}$ Fr, abiotic depletion fossil fuels; GWP100a, global warming potential or climate change; ODP, ozone layer depletion; HT, human toxicity; FWE, fresh water aquatic ecotoxicity; MAE, marine aquatic ecotoxicity; TE, terrestrial ecotoxicity; PO, photochemical oxidation; AA, air acidification; EU, eutrophication. 


\section{References}

Bouwman AE, 1995. Compilation of a Global Inventory of Emissions of Nitrous Oxide. Ph.D. thesis. University of Wageningen, Netherlands.

Brentrup F, Küsters J, Lammel J, Kuhlmamm H, 2000. Methods to estimate on field nitrogen emissions from crop production as an input to LCA studies in the agricultural sector. Int. J. Life Cycle Assess. 5:349-57.

Catizone P, Barbanti L, Marotti I, Dinelli G, 2013. Produzione e impiego delle piante officinali, Pàtron Editore, Bologna, Italy.

Cerutti AK, Beccaro GL, Bruun S, Bosco S, Donno D, Notarnicola B, Bounous G, 2014. Life cycle assessment application in the fruit sector: state of the art and recommendations for environmental declarations of fruit products. J. Clean. Prod. 73:125-35.

CML, Bureau BG, School of System Engineering, Policy Analysis and Management, Delft University of Technology 2001. Life cycle assessment: an operational guide to the ISO standards.

Consoli F, Allen D, Boustead I, Fava J, Franklin W, Jensen AA, De Oude N, Parrish R, Perriman R, Postletwaite D, Quay B, Sèguin J, Vignon B, 1993. (Eds.) Guidelines for life $\square$ cycle assessment: A "Code of Practice". Society of Environmental Toxicology and Chemistry (SETAC), Brussels.

Decree of Ministry of the Environment, No 152, 03/04/2006, Gazzetta Ufficiale. Available from: http://www.gazzettaufficiale.it/atto/ serie generale/caricaDettaglioAtto/originario?atto.dataPubblicazio neGazzetta=2006-04-14\&atto.codice Redazionale=006G0171

De Falco E, Mancini E, Roscigno G, Mignola E, Taglialatela-Scafati O, Senatore F, 2013. Chemical Composition and biological activity of essential oils of Origanum vulgare L. ssp. vulgare L. under different growth conditions. Molecules 8:14948-60.

De Falco E, Roscigno G, Landolfi S, Scandolera E, Senatore F, 2014. Growth essential oil characterization, and antimicrobial activity of three wild biotypes of oregano under cultivation condition in Southern Italy. Ind Crop Prod 62:242-9.

Eltawil MA, Azam AA, Alghannam AO, 2018. Energy analysis of hybrid solar tunnel dryer with PV system and solar collector for drying mint (MenthaViridis). J. Clean. Prod. 181:352-64.

European Commission, 2014. Rural development 2014-2020. Available from: https://ec.europa.eu/agriculture/rural-development-20142020_en

European Pharmacopoeia, 2005. Published in accordance with the Convention on the elaboration of a European pharmacopoeia. Strasbourg: Council of Europe. Available from: https://www.edqm. eu/medias/fichiers/1964_PhEur_Convention_English.pdf

FAOstat, 2016. Available from: http://www.fao.org/faostat /en/\#home Accessed: 04 April 2018.

Fedele A, 2010. Gli impatti ambientali di un ciclo colturale triennale secondo la metodologia LCA: tecniche convenzionali e biologica a confronto. Tesi di laurea in ingegneria chimica per lo sviluppo sostenibile. Università di Padova, Italy.

Fernandez-Lopez J, Perez-Alvarez JA, Viuda-Martos M, 2012. Beneficial health effects of bioactive compounds present in spices and aromatic herbs. Bioact. Nat. Prod. 37:115-34.

Gallego MG, Gordon MH, Segovia FJ, Skowyra M, Almajan MP, 2013. Antioxidant Properties of Three Aromatic Herbs (Rosemary, Thyme and Lavender) in Oil-Water Emulsions. J. Am. Oil Chem. Soc. 90:1559-68.

International Standards Organisation, 2006a. ISO 14044:2006 Environmental Management Life Cycle Assessment and Requirements and Guidelines. International Standards Organisation, Geneva, Switzerland.
International Standards Organisation, 2006b. ISO 14040:2006 Environmental Management Life Cycle Assessment and Principles and Framework. International Standards Organisation, Geneva, Switzerland.

IPCC (Intergovernmental Panel on Climate Change), 2006. Guidelines for National Greenhouse Gas Inventories, vol. 11. Agriculture, Forestry and Other Land Use, USA.

ISMEA, 2013. Osservatorio Economico del settore delle piante officinali. Piante officinali in Italia: un'istantanea della filiera e dei rapporti tra i diversi attori. Available from: http://www.ismea.it/flex/ $\mathrm{cm} /$ pages/ServeBLOB.php/L/IT/IDPagina/8744

Jayasena DD, Jo C, 2014. Potential Application of Essential Oils as NaturalAntioxidants in Meat and Meat Products: A Review. Food Rev. Int. 30:71-90.

Müller J, Heindl A, 2006. Drying of medicinal plants. In Medicinal and aromatic plants - agricultural, commercial, ecological, legal, pharmacological and social aspects. Springer 237-52.

Nemecek T, Kägi T, 2007. Life cycle Inventory of Agricultural Production Systems. Swiss Centre for Life Cycle Inventories, Dübendorf. Ecoinvent report 15.

Paur I, Carles MH, Halvorsen BH, Blomhoff R, 2011. Antioxidant in herbs and spice. NCBI Bookshelf ID: NBK92763; Benzie IFF, Wachtel - Galor S, Editors. Boca Raton (FL); CRC Press Taylor and Francis Group, Boca Raton, FL, USA.

Pergola M, Persiani A, Pastore V, Palese AM, Arous A, Celano G, 2017. A comprehensive Life Cycle Assessment (LCA) of three apricot orchard systems located in Metapontino area (Southern Italy). J. Clean. Prod. 142:4059-71.

PRé, various authors, 2015. SimaPro Database Manual Methods Library. Available from: https://www.pre-sustainability.com/ simapro-database-and-methodslibrary Accessed: 14 April 18.

Regione Campania, 2013. Il territorio rurale della Campania. Un viaggio nei sistemi agroforestali della regione attraverso i dati del $6^{\circ}$ Censimento Generale dell'Agricoltura - Imago Editrice s.r.l. Dragoni (CE), Italy.

Rocha RP, Melo EC, Radünz LL, 2011. Influence of drying process on the quality of medicinal plants: A review. J. Med. Pl. Res. 5:707684.

Ronga D, Gallingani T, Zaccardelli M, Perrone D, Francia E, Milc J, Pecchioni N, 2019. Carbon footprint and energetic analysis of tomato production in the organic vs the conventional cropping systems in Southern Italy. J. Clean. Prod. 220:836-45.

Santos J, Herrero M, Mendiol JA, Oliva-Teles MT, Ibáñez E, DelerueMatos C, Oliveira MBPP, 2014. Fresh - cut aromatic herbs: Nutritional quality stability during shelf - life. Food Sci. Technol. 59:101-7.

Senatore F, Oliviero F, Scandolera E, Taglialatela Scafati O, Roscigno G, Zaccardelli M, De Falco E, 2013. Chemical composition, antimicrobial and antioxidant activities of an ethole - rich oil from leaves of selected varieties of fennel [Foeniculum vulgare Mill. ssp. vulgare var. Azoricum (Mill.) Thell]. Fitoterapia 90:214-9.

Solórzano-Santos F, Miranda-Novales MG, 2012. Essential oils from aromatic herbs as antimicrobial agents. Curr. Opin. Biotech. 23:136-14.

Vitalini S, Tomè F, Fico G, 2009. Traditional uses of medicinal plants in Valvestino (Italy). J. Ethno. Pharmacol. 121:106-16.

Viuda-Martos M, Ruiz-Navajas Y, Fernández-Lopez J, 2011. Spices as functional foods. Crit. Rev. Food Sci. 51:13-28.

World Health Organization (WHO), 2011. Quality control methods for herbal materials; updated edition of 1998. Available from: http://apps.who.int/iris/bitstream/handle/10665/44479/9789241500 739 eng.pdf;sequence $=1$ 